\title{
Aspecte clinico-epidemiologice şi evolutive privind primii 20 de pacienți cu COVID-19, internați în Spitalul Clinic de Boli Infecțioase şi Tropicale „Dr. Victor Babeş“
}

\author{
Andreea Florentina Stoenescu ${ }^{1,2}$, Alexandru Cosmin Marin', George Gherlan ${ }^{1,2}$, \\ Corneliu Petru Popescu',2, Sebastian Smadu', Ana Maria Veja1, Adelina Dogaru1, \\ Filofteia Cojanu-Banicioiu', Nicoleta Voicu-Parvu ${ }^{1}$, Luminița Ene ${ }^{1}$, Petre Calistru ${ }^{1,2}$, \\ Emanoil Ceauşu ${ }^{1,2}$, Simin-Aysel Florescu ${ }^{1,2}$ \\ ${ }^{1}$ Spitalul Clinic de Boli Infecţioase şi Tropicale „Dr. Victor Babeş“, Bucureşti, România \\ Universitatea de Medicină şi Farmacie „Carol Davila“, Bucureşti, România
}

\begin{abstract}
REZUMAT
În Spitalul Clinic de Boli Infecţioase şi Tropicale „Dr. Victor Babeş“, primii pacienţi cu COVID-19 au fost internaţi în luna martie 2020.

Dintre cei 20 de pacienţi, 11 au fost de sex masculin si 9 de sex feminin. Pacienţii au avut vârste cuprinse între 3 şi 56 de ani. 8 pacienţi au locuit sau călătorit în afara României in perioada de incubaţie a bolii. Cele mai frecvente simptome au fost febra, tusea seacă şi dificultăţi respiratorii. 2 pacienţi au prezentat forme severe de boală ce au necesitat transfer în secţia de terapie intensivă. Radiologic, 18 pacienţi au prezentat afectare pulmonară interstiţială. Toţi pacienţii au avut evoluţie favorabilă.
\end{abstract}

Cuvinte cheie: COVID-19, primii pacienţi, epidemiologie, clinică

\section{INTRODUCERE}

Coronavirusurile aparţin familiei Coronaviridae, din ordinul Nidovirales, sunt virusuri cu genom ARN pozitiv, anvelopate, iar proiecţiile glicoproteice de la acest nivel sugerează aspectul de halou sau ,coroană“ vizibil la microscopia electronică (1). Există 4 genuri, alfa, beta, gama, delta, dintre care primele 2 afectează mamiferele (2).

Virusul se transmite predominant pe cale aeriană, prin secreţii respiratorii, dar şi pe cale fecal-orală. Incubaţia variază între 3 şi 14 zile (3). Infecţia poate fi asimptomatică, uşoară, moderată sau severă, chiar fatală. Principalele simptome sunt reprezentate de febră, tuse, dispnee, cefalee, mialgii, anosmie, disgeu- zie, diaree, vărsături (4). În formele severe pot fi prezente insuficienţa respiratorie, sindromul de detresă respiratorie acută, şocul septic, insuficienţa/disfuncţia multiplă de organ (5).

Coronavirusurile reprezintă o problemă importantă de sănătate publică deoarece pot depăşi bariera de specie. Astfel, în perioada 2002-2003, a izbucnit prima epidemie cauzată de SARS-CoV (Severe Acute Respiratoy Syndrome - Coronavirus) cu o rată de fatalitate de $10 \%(6,7)$, iar în 2012, epidemia cauzată de MERS (Middle East Respiratoy Syndrome), rata de fatalitate în acest caz fiind de 36\% (8).

Noul coronavirus, cunoscut sub numele de SARSCoV-2, a fost identificat în ianuarie 2020, după ce la finalul anului precedent au fost raportate numeroase 
cazuri de pneumonie atipică în oraşul Wuhan din China. Numărul cazurilor de infecţie produsă de acest virus s-a extins rapid, la nivelul tuturor continentelor, Organizaţia Mondială a Sănătăţii declarând pe 11 martie pandemia COVID-19.

În Europa, Italia a fost prima ţară care a înregistrat un număr semnificativ de pacienţi diagnosticaţi cu infecţie SARS-CoV-2. Dintre aceştia, un procent important a prezentat o formă severă de boală, fiind necesară internarea în secţiile de Terapie Intensivă (9).

În România, epidemia a debutat pe data de 26 februarie 2020, cu primul caz diagnosticat în judeţul Gorj, un pacient contact cu un cetăţean italian.

Primele cazuri s-au internat în Spitalul Clinic de Boli Infecţioase şi Tropicale „Dr. Victor Babeş“ în data de 9 martie, 3 membri ai aceleiaşi familii.

\section{OBIECTIV}

Identificarea caracteristicilor epidemiologice şi clinico-biologice ale pacienţilor.

\section{MATERIALE ŞI METODE}

Studiu retrospectiv, observaţional, pe un lot de 20 de pacienţi internaţi şi trataţi în Spitalul Clinic de Boli Infecţioase şi Tropicale „Dr. Victor Babeş“ din Bucureşti.

Diagnosticul de COVID-19 a fost stabilit prin intermediul testelelor moleculare tip PCR din exsudat nazo-faringian.

Datele epidemiologice, caracteristicile clinice şi rezultatele probelor biologice au fost obţinute din foile de observaţie ale pacienţilor.

\section{REZULTATE}

Lotul de pacienţi studiat este format din 11 bărbaţi şi 9 femei cu vârste cuprinse între 3 ani şi 56 de ani. Vârsta medie este 34,45 ani, cu mediana de 35,5 ani. 3 pacienţi au avut vârsta sub 18 ani. Din punct de vedere epidemiologic, 8 pacienţi au fost diagnosticaţi cu COVID-19 în urma reîntoarcerii în România din Germania (2 pacienţi), Londra (2 pacienţi) şi câte 1 pacient din Israel, Spania, Austria, Norvegia. Ceilalţi 12 pacienţi au fost cadre medicale din Spitalul Gerota, unde un pacient întors recent din o excursie în Israel s-a internat cu o simptomatologie necaracteristică pentru COVID-19, dar care ulterior a evoluat spre o formă severă de boală şi care a infectat 50 de membri ai echipei medicale.
Toţi pacienţii provin din mediul urban, majoritatea sunt nefumători şi neagă consumul excesiv de alcool.

Din punctul de vedere al severităţii, 18 pacienţi au avut forme uşoare de boală, iar 2 pacienţi - forme severe ce au necesitat transfer în secţia de terapie intensivă.

14 pacienţi nu au avut afecţiuni asociate. O pacientă prezenta sarcină în evoluţie (S29) şi BRD minor, un pacient diabet zaharat de tip 2 în tratament cu antidiabetice orale, iar un alt pacient sarcoidoză. Dintre pacienţii cu forme severe, unul prezenta obezitate grad 2, DZ tip 2 dezechilibrat, iar cel de-al doilea obezitate morbidă şi sindrom de apnee in somn obstructivă, cu necesar de oxigen la domiciliu.

Cele mai frecvente simptome la internare au fost febra (17 pacienţi), tusea seacă (10 pacienţi), odinofagia (8 pacienţi), frisoanele (5 pacienţi), dificultăţi în respiraţie (4 pacienţi), mialgii, anosmie şi disgeuzie (3 pacienţi), iar un pacient a acuzat manifestări digestive (scaune apoase). Cel mai adesea, pacienţii au asociat febră şi tuse (9 pacienţi), urmate de febră, tuse şi dificultate în respiraţie (4 pacienţi).

Din punct de vedere biologic, 17 pacienţi au prezentat sindrom inflamator moderat-uşor, înregistrându-se modificări ale proteinei $\mathrm{C}$ reactive, ale VSH şi ale fibrinogenului. 12 pacienţi au asociat limfocitopenie, iar 3 pacienţi - hepatocitoliză. Examenul radiologic pulmonar a evidenţiat la 12 pacienţi desen interstiţial accentuat bazal bilateral ( 7 bărbaţi, 5 femei), la 6 pacienţi afectare interstiţială unilaterală, iar 2 pacienţi nu au prezentat nicio modificare radiologică.

În cazul pacienţilor cu formă uşoară de boală, numărul de zile de spitalizare a variat între 10 şi 25 de zile, cu o medie de 12,7 zile, fără o corelaţie clară cu simptomatologia sau vârsta. Pacienţii cu forme severe au avut nevoie de 31 de zile de spitalizare. Externarea nu s-a facut după criteriul clinic, ci după cel epidemiologic (2 determinări, PCR negativ din exsudatul nazo-faringian la interval de 24 de ore).

Formele uşoare care au asociat modificări radiologice au fost tratate cu Hidroxiclorochină asociată cu Azitromicină, iar formele cu imagine radiologică normală au primit doar Hidroxiclorochină şi simptomatice.

Pacienţii cu o formă gravă de boală au fost admişi în Secţia de Terapie Intensivă şi au necesitat în plus oxigenoterapie, suport hidroelectrolitic şi acidobazic, vitaminoterapie, gastroprotecţie, heparină cu greutate moleculară mică în doză profilactică, corticoterapie, 
Lopinavir/Ritonavir şi antibioterapie cu spectru larg. Deoarce răspunsul terapeutic iniţial a fost nefavorabil, s-a administrat inhibitor de IL-6, cu o evoluţie lentă favorabilă din punct de vedere clinic, biologic şi radiologic.

\section{DISCUȚII}

Studiul prezent oferă un rezumat al tabloului infecţiei cu virusul SARS-CoV-2, la debutul acesteia în România.

În literatura de specialitate, primele studii referitoare la infecţia cu SARS-CoV-2 provin din China, unde au fost înregistrate primele cazuri. Acestea sugerează că vârsta înaintată, sexul masculin şi prezenţa comorbidităţilor sunt potenţiali factori de risc pentru o formă severă de boală $(10,11)$. În studiul prezent, ambii pacienţi cu forme severe de boală au fost de sex masculin, 1 pacient suferea de obezitate grad 2, DZ tip 2 dezechilibrat, iar cel de-al doilea de obezitate morbidă şi sindrom de apnee în somn obstructivă, cu necesar de oxigen la domiciliu.

Un alt studiul efectuat de către Tabata şi colab. (12), asupra unui lot ce cuprinde 104 pacienţi confirmaţi cu COVID-19, aflaţi la bordul vasului de croazieră Diamond Princess, sugerează că prezenţa limfocitopeniei la debutul bolii, vârsta înaintată şi prezenţa comorbidităţilor au fost mai frecvente la pacienţii cu forme severe ( 28 de pacienţi au dezvoltat forme severe, din totalul de 104 incluşi în studiu). În ceea ce priveşte lotul actual, pacienţii care au dezvoltat forme severe nu aveau vârste înaintate, însâ amândoi asociau comorbidități, iar limfocitopenia a fost prezentă de la momentul admisiei în spital.

Referitor la aspectul radiologic, studiile din China arată că, cel mai frecvent, afectarea pulmonară este bilaterală, la nivelul câmpurilor pulmonare inferioare, periferic $(13,14)$, caracteristici regăsite şi în lotul studiat. La cei 2 pacienţi cu formă severă de boală, a fost observată pe radiografia pulmonară apariţia focarelor de condensare cu dispunere bilaterală, respectiv a infiltratelor alveolo-interstiţiale, mai ales la nivelul câmpurilor pulmonare inferioare, cu o creştere în intensitate şi arie de proiecţie concomitent cu evoluţia nefavorabilă a bolii (scăderea Sa02, apariţia dispneii şi a polipneii). Acese tipuri de leziuni au fost regăsite şi la pacienţii diagnosticaţi cu COVID-19 incluşi în studiul realizat de Shi şi colab. Deşi investigaţia paraclinică efectuată în studiul acestuia a fost examenul CT, şi în acest caz s-a observat dispunere bilaterală şi periferică a opacităţilor în geam mat, care, odată cu evoluţia bolii, s-au înmulţit şi au fost înlocuite de consolidare pulmonară (15). Astfel, agravarea imaginii radiologice poate fi un factor de risc pentru prognosticul rezervat al pacienţilor cu COVID-19, alături de celelalte variabile (vârsta înaintată, sexul masculin, comorbidităţile asociate).

\section{CONCLUZII}

Din punct de vedere epidemiologic, toate cazurile au fost conectate cu pacienţi din import. În 8 cazuri, contactul infectant s-a produs în afara ţării, iar în 12 cazuri - în ţară, dar plecând de la un caz de import, un model clar de boală asociată medicinei călătoriei. Simptomul cardinal a fost febra, urmat de tuse seacă şi odinofagie. Din punct de vedere biologic, s-au înregistrat modificări minime, iar din punct de vedere radiologic au fost înregistrate modificări la 18 pacienţi.

Majoritatea pacienţilor au avut forme uşoare de boală. Numărul de zile de spitalizare a fost, în medie, 12,7 zile la pacienţii cu forme uşoare şi medii de boală, respectiv 31 de zile la pacienţii cu forme severă. Obezitatea, sexul masculin, valoarea scăzută a limfocitelor au fost factori de risc determinanţi pentru evoluţia spre o formă severă de boală.

Evoluţia a fost favorabilă în toate cazurile şi nu s-a înregistrat niciun deces.

\section{$\overline{\text { BIBLIOGRAFIE }}$}

1. Liu J, Zheng X, Tong $Q$ et al. Overlapping and discrete aspects of the pathology and pathogenesis of the emerging human pathogenic coronaviruses SARS-CoV, MERS-CoV, and 2019-nCoV. J Med Virol. 2020;92:491-494.

2. Perlman S, Netland J. Coronaviruses post-SARS: Update on replication and pathogenesis. Nat Rev Microbiol. 2009;7:439-50.

3. Lauer SA, Grantz KH, Bi Q, Jones FK, Zheng Q, Meredith HR, Azman AS, Reich NG, Lessler J. The Incubation Period of Coronavirus Disease 2019 (COVID-19) From Publicly Reported Confirmed Cases: Estimation and Application. Ann Intern Med. 2020;172(9):577-582.

4. Huang C, Wang Y, Li X, Ren L, Zhao J, Hu Y, Zhang L et al. Clinical features of patients infected with 2019 novel coronavirus in Wuhan, China. Lancet. 2020;395(10223):497-506.

5. Wu Z, McGoogan JM. Characteristics of and Important Lessons From the Coronavirus Disease 2019 (COVID-19) Outbreak in China: Summary of a Report of 72,314 Cases From the Chinese Center for Disease Control and Prevention. JAMA. 2020.

6. Ksiazek TG, Erdman D, Goldsmith CS, Zaki SR, Peret T et al. A novel coronavirus associated with severe acute respiratory syndrome. N Engl J Med. 2003;348:1953-66. 
7. Rota PA, Oberste MS, Monroe SS, Nix WA, Campagnoli R et al. Characterization of a novel coronavirus associated with severe acute respiratory syndrome. Science. 2003;300:1394-99.

8. Zaki AM, van Boheemen S, Bestebroer TM, Osterhaus AD, Fouchier RA. Isolation of a novel coronavirus from a man with pneumonia in Saudi Arabia. N Engl J Med. 2012;367(19):1814-20.

9. Grasselli G, Zangrillo A, Zanella A et al. Baseline characteristics and outcomes of 1591 patients infected with SARS-CoV-2 admitted to ICUs of the Lombardy region, Italy. JAMA. 2020;323:1574-1581.

10. Huang $C$, Wang $Y, L i X$ et al. Clinical features of patients infected with 2019 novel coronavirus in Wuhan, China. Lancet. 2020;395:497-506.

11. Yang J, Zheng Y, Gou X et al. Prevalence of comorbidities in the novel Wuhan coronavirus (COVID-19) infection: A systematic review and meta-analysis. Int J Infect Dis. 2020;94:91-95.

12. Tabata S, Imai K, Kawano S, Ikeda M et al. Clinical characteristics of COVID-19 in 104 people with SARS-CoV-2 infection on the „Diamond
Princess cruise" ship: A retrospective analysis. The Lancet Infectious Diseases, 2020.

13. Yoon SH, Lee KH, Kim JY, Lee YK et al. Chest Radiographic and CT Findings of the 2019 Novel Coronavirus Disease (COVID-19): Analysis of Nine Patients Treated in Korea. Korean Journal of Radiology. 2020;21(4):494-500.

14. Ng MY, Lee EY, Yang F, Li X, Wang H, Lui MM, Lo CSY et al. Imaging Profile of the COVID-19 Infection: Radiologic Findings and Literature Review. Radiology: Cardiothoracic Imaging. 2020;2(1).

15. Shi H, Han X, Jiang N, Cao Y, Alwalid O, Gu J, Fan Y, Zheng C. Radiological findings from 81 patients with COVID-19 pneumonia in Wuhan, China: A descriptive study. The Lancet Infectious Diseases. 2020;20(4):425-434.

Conflict of interest: none declared Financial support: none declared 